\title{
Tachydromia calcarata (Strobl) (Diptera: Hybotidae) new to Britain, with redescription of both sexes, and its correct classification within the $T$. interrupta group of species
}

\author{
Milan Chvála \& Stephen M. Hewitt
}

Chvála, M. \& Hewitt, S. M. 2006: Tachydromia calcarata (Strobl) (Diptera: Hybotidae) new to Britain, with redescription of both sexes, and its correct classification within the T. interrupta group of species. - Entomol. Fennica 17: 8-12.

First record of Tachydromia calcarata (Strobl) (Diptera: Hybotidae) from the British Isles, and outside the Continental Alpine region, is reported here. Both sexes are redescribed, female for the first time, and the species re-classified within the predominantly mountain $T$. interrupta group (formerly assigned as a member of the $T$. connexa group).

Milan Chvála, Department of Zoology, Charles University, Viničná 7, CZ-128 44 Praha 2, Czech Republic; E-mail: mchvala@natur.cuni.cz

Stephen M. Hewitt, Tullie House Museum, Castle Street, Carlisle CA3 8TP, U. K.; E-mail: SteveH@carlisle-city.gov.uk

Received 1 April 2005, accepted 12 July 2005

\section{Introduction}

In spring 2004 the author SMH, together with John Parker, found a seemingly unknown British Tachydromia species in north Cumbria, not far from the locality from where $T$. edenensis Hewitt \& Chvála was described in 2002. Using the key to the Palaearctic species (Chvála 1970), the specimens fitted closely with a redescription and illustrations of a then poorly known Austrian species, T. calcarata (Strobl, 1910) that was described on the basis of a single male collected on the bank of the River Enns near Admont in the Styrian Alps. For details on the holotype, see Chvála (2003).

\section{Results}

\subsection{Systematic position of Tachydromia calcarata (Strobl, 1910)}

Strobl (1910) described T. calcarata (in the genus
Tachysta) as a species closely related to $T$. tuberculata (Loew) of the T. connexa group (sensu Chvála 1970), differing in having "femoribus interm. non tuberculatis, tibiis calcaratis, tarsorum basi flava, hypopygio parvo", but with the same wing pattern: "die 2 Flügelbinden nur ganz hinten durch einen hellen Fleck getrennt sind". The species was fully redescribed within a revision of Palaearctic Tachydromia species by Chvála (1970) after examination of the, at that time, unique original male housed in the Strobl Collection in Admont. However, the holotype was headless and thus the redescription lacked the important classification characters of the head. The other characters, especially the wing pattern, led the author (MC) to follow Strobl (1910) and to classify $T$. calcarata within the $T$. connexa group, as a species closely related to $T$. tuberculata (Loew) and T. costalis (von Roser). It is curious that Strobl (1910) did not mention in his rather detailed original description any morphological feature on the head of $T$. calcarata. It 
seems unlikely that it was already headless at that time, as it would have been out of character for Strobl not to mention the lack of a head had it been missing at that stage.

Examination of the specimens of T. calcarata recently found in Britain proves the species has been wrongly classified up to now. All the main characters on the head clearly show it is a representative of the Tachydromia interrupta group of species, even the wing pattern of the fairly long wings having been previously misunderstood. The $T$. interrupta group now includes seven species in Europe, of these five (T. obsoleta (Strobl, 1910), T. nigerrima (Bezzi, 1918), T. interrupta (Loew, 1864), T. styriaca (Strobl, 1893) and T. gorodkovi Shamshev, 1993) are continental mountain species, one (T. pseudointerrupta Chvála, 1970) is known in the Canary Islands and the seventh, T. calcarata (Strobl, 1910), described from the Alpine region, is now also known in the British Isles.

The Tachydromia connexa group of species is characterised by several specific characters of the head: (1) the very short antennal arista, which is at most 3 times as long as the antenna, (2) the small palpi, and (3) the small ocellar, postvertical and occipital setae. Furthermore, the species generally have 2 notopleural bristles - the anterior one usually only slightly weaker than the posterior. Also rather short, wide, and blunt-ended wings with the two brown cross-bands broadly connected anteriorly, at least in cells R1 and R3, very often even cell R5 is extensively brownish, and the base of the male mid femur bears a characteristic spinose excision, or a distinct tubercle, below. Male genitalia are distinctively large and globose, with the right lamella bearing a specifically enlarged foot-like dorsal process. The lack of the genital and leg characters differentiated $T$. calcarata from all other species of the $T$. connexa group.

All the main characters on the head of the British specimens of T. calcarata (Fig. 1) clearly show the species does not belong to the $T$. connexa species group. There are 3 pairs of very distinctive, long occipital setae, the palpi are long and slender, and the antennal arista is very long and thread-like, about 5 times as long as the antenna. In particular, the long setae on the occiput, with the low placement of the postverticals
Fig. 1.

Tachydromia calcarata; head.

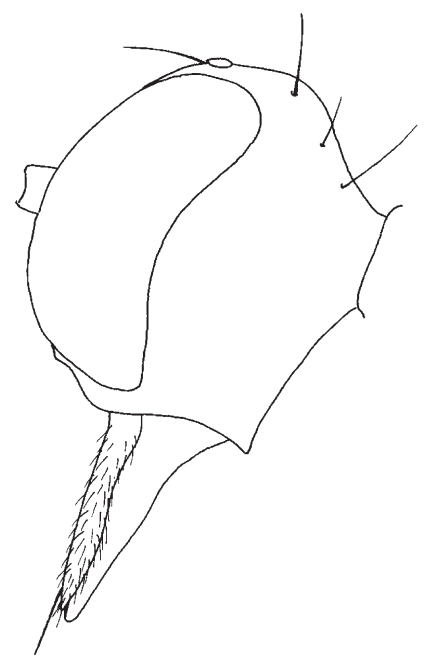

clearly indicates the $T$. interrupta group. It is now clear that the wing pattern was misinterpreted by both Strobl (1910) and Chvála (1970), as the two brown cross-bands on the wing (Fig. 2) are completely connected in the cell R5, but are slightly interrupted by an indistinct paler patch above in cell R3. Thus, the two cross-bands are clearly connected in the cell R5 (a differential feature of the T. interrupta group) but, compared with other species of this group, the bands are broadly connected in T. calcarata with no hyaline area in cell $\mathrm{R} 1$ and only a slight separation in cell R3. The fairly long and more pointed wings, together with the simple mid femur in the male (without any excision or tubercle beneath at base) and the characteristic small male genitalia, clearly show that T. calcarata should be reclassified within the T. interrupta species group.

\subsection{Redescription of Tachydromia calcarata (Strobl)}

Male. Head as in Fig. 1, with frons about as wide as 3rd antennal segment (postpedicel), only very

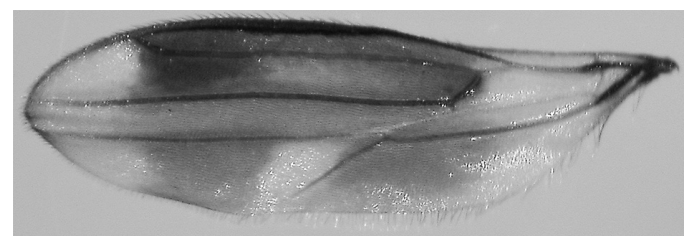

Fig. 2. Tachydromia calcarata; wing. 
indistinctly widening towards vertex, polished black, leaving only a small patch just above antennae and an indication of a small triangular face below antennae dull dark grey. Eyes meeting on face, all ommatidia almost equally small. A small patch behind ocelli polished black like frons, otherwise upper part of occiput including postocular margins uniformly densely dark grey dusted, leaving lower part below neck with a tendency to be subshining black, and clearly polished black towards mouth. All bristles and hairs on head dark: pair of posterior ocellar bristles (inserted anteriorly between hind ocelli) fairly long, about as long as 3rd antennal segment; pair of postverticals still longer, inserted very low at about 1/3 distance from ocelli to neck, with another pair of smaller and finer occipital bristles below and yet another pair of much longer and thinner bristles low down above the neck. Antennae blackish with very short, yellowish pruinescence, short basal segment (scape) inconspicuous, 3rd segment (postpedicel) short ovate with very long, thin supraapical arista at least 5 times as long as rest of antenna. Palpi blackish brown, long and slender, as long as proboscis, covered with sparse, short silvery hairs, and black supraapical seta about one-third length of palpus.

Other parts of body as redescribed by Chvála (1970), with thorax shining black (more brownish in the old type specimen), leaving prothorax and upper part of fore coxa silvery dusted, and postalar calli including scutellum dull greyish. All thoracic hairs and bristles black: humeri with about 3 small fine hairs, dorsocentrals uniserial, about 6 hair-like bristles in row, with posterior prescutellar pair longest, acrostichals lacking. Usually 1 strong notopleural bristle, often with another much smaller bristle anteriorly, 1 fine supraalar, and 2 pairs of scutellar bristles, outer pair finer and of half-length of apical pair.

Wing as in Fig. 2, with the two brown bands broadly connected on costal half right up to vein $\mathrm{M}$; base of wing to radial sector, and wing-apex beyond tip of vein $\mathrm{R} 2+3$, whitish; vein $\mathrm{R} 2+3$ straight and lying closer to costa, thus cell R1 narrower than the cell R3. Haltere whitish yellow.

Legs long and slender, only fore femur thickened, much stouter than posterior four femora. Legs extensively blackish, especially hind pair, but fore coxa contrasting yellowish, as are basitarsi (basal tarsomeres) of all legs except darkened tips; anterior four "knees" also yellowish, and mid femur lighter, pale brownish, especially below. All coxae covered with fairly long pale setae, femora densely short silvery pilose beneath, fore femur with ventral row of fine black bristly hairs scarcely longer than silver pile, similar black bristly hairs also on mid femur (becoming longer towards base), and those on hind femur slightly longer, finer and more adpressed. Tibiae with rather dense short black pubescence, fore tibia spindle-shaped towards tip, clearly stouter than long slender mid and hind tibiae; mid tibia with ventral row of small, stubby black bristles (more distinct on apical two-thirds) and short pointed ventral apical projection. Tarsi long and slender, mid basitarsus as long as following two tarsomeres, and whole tarsus clearly longer than tibia; same applies to hind legs. In contrast to species of $T$. connexa group (except $T$. edenensis), mid tibia is fairly long, almost as long as corresponding femur and latter is simple, without any excavation or tubercle at base beneath [see Chvála (1970): 477, figure 52].

Abdomen shining black on dorsum, almost bare, sterna dulled by dark greyish dusting and finely black pubescent, longer at sides. Genitalia [see Chvála (1970), figure 53] small, narrower than reduced apical two abdominal segments. Lamellar appendages small, as are cerci, projection of right lamella clearly bifurcated and both lobes strongly spinose apically.

Length. Body $2.0 \mathrm{~mm}$, wing $1.8 \mathrm{~mm}$.

Female. Very much like male, differing only in absence of small pointed apical spur on mid tibia, and in terminalia. Head with same bristling and dusting on vertex and occiput, slender antennal arista apparently slightly longer. Thorax and wings as in male, and legs of same structure and colouration (only mid tibial spur absent). Abdomen bare on shining black terga, sterna dull dark grey and covered by fine, short black pubescence; cerci small and slender, dull grey.

Length. Body 2.2-2.7 mm, wing 2.1-2.3 mm.

In Collin's (1961) and Chvála's (1973) keys to British Tachydromia [as Sicodus in Collin (1961)], T. calcarata will end up in couplet 4(5) and 5(6), respectively; species with occiput dull silvery grey, differing from $T$. halidayi (a small species with body about $1.5 \mathrm{~mm}$ long, whitish 


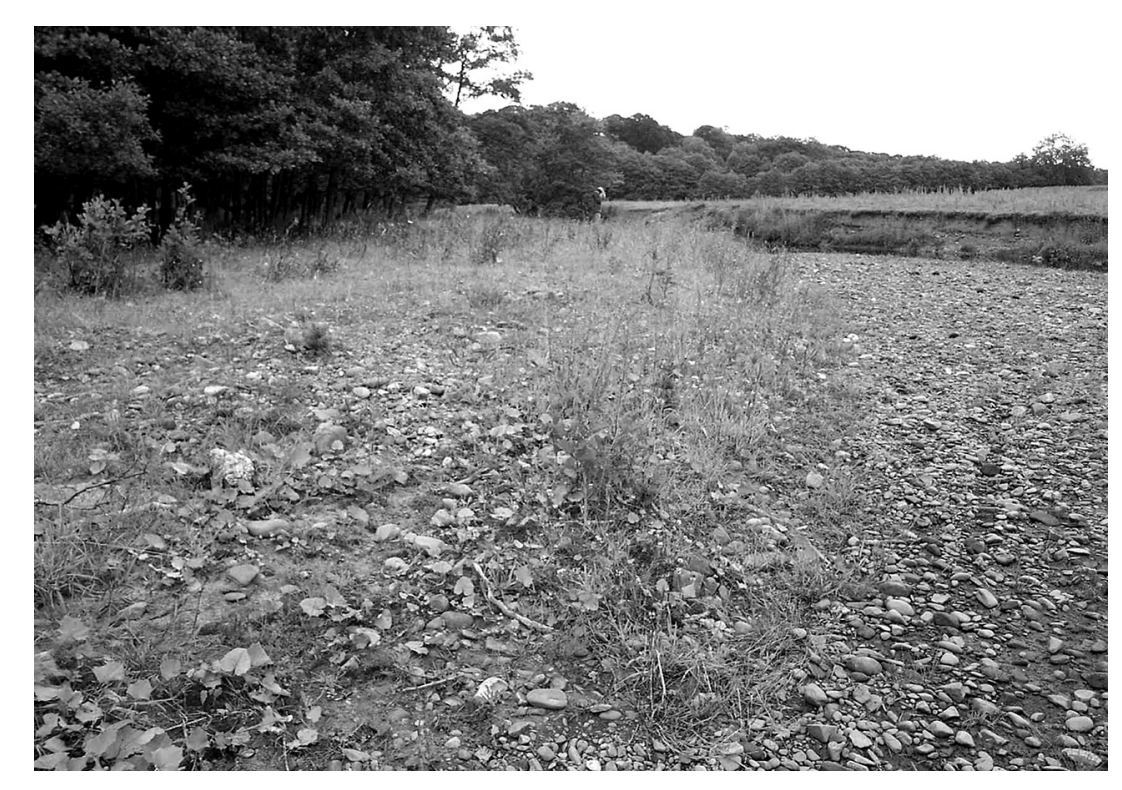

Fig. 3. Sand/shingle bar habitat of Tachydromia calcarata on the King Water river, Cumbria, England.

yellow palpus, and wings with two faint brownish bands at most indistinctly connected along costal margin) in the larger size, body about $2-2.5 \mathrm{~mm}$ long, blackish brown palpus, and the distinct brownish bands on wing broadly connected in costal half. In Chvála's (1975) key to Scandinavian Tachydromia the species will lead to couplet 7(5), to T. arrogans group of species, close to $T$. lundstroemi (Frey, 1913), which is a larger-sized species (body length 2.8-3.3 mm) with brownish wing bands very indistinct posteriorly and widely separated throughout.

\subsection{Distribution}

The species was previously known only from the single type specimen collected from the River Enns at Admont in the Styrian Alps of Austria on 14 July 1901 . This locality is about $620 \mathrm{~m}$ above sea level, comprising partly marshy, partly gravel or stony riverbank. In Britain T. calcarata was first discovered near Walton, Cumbria in the north of England on 5 June 2004 (Hewitt et. al. 2005). The site is a sand and shingle bar on the King Water, a small river at an altitude of about 55 $\mathrm{m}$. Numerous adults were present on unshaded, stabilised, damp sand with scattered vegetation of mainly grasses and Tussilago farfara. The flies were concentrated among the grasses along the damp transition slope of the stabilised bank and the lower lying more pebbly shingle adjacent to the river (Fig. 3). Further survey revealed the species to be present on three other sandy shingle banks downstream on a $1.5 \mathrm{~km}$ stretch of the King Water and at a further site nearby, at Lanercost Holmehead on the River Irthing, of which the King Water is a tributary (Fig. 4). The flies were concentrated on areas of damp, sparsely vegetated sand at all sites. Both rivers flow off Carboniferous sandstones and limestones of the Cheviot Hills, with their headwaters in areas of, now largely coniferised, blanket bog.

Adults were first found on 5 June and were last noted on 31 July. Other species of Tachydromia also present at $T$. calcarata localities, although not necessarily in the same zone of the shingle banks, were T. morio (Zetterstedt, 1838) (numerous), T. costalis (von Roser, 1840) (few), T. acklandi Chvála, 1973 (numerous), T. halidayi (Collin, 1926) (frequent), T. aemula (Loew, 1864) (few) and T. woodi (Collin, 1926) (rare). Stilpon nubilus Collin, 1926 was also frequent on sand at one site on the King Water.

\section{Discussion}

The finding of Tachydromia calcarata (Strobl) in the north west of the British Isles is a real surprise, 


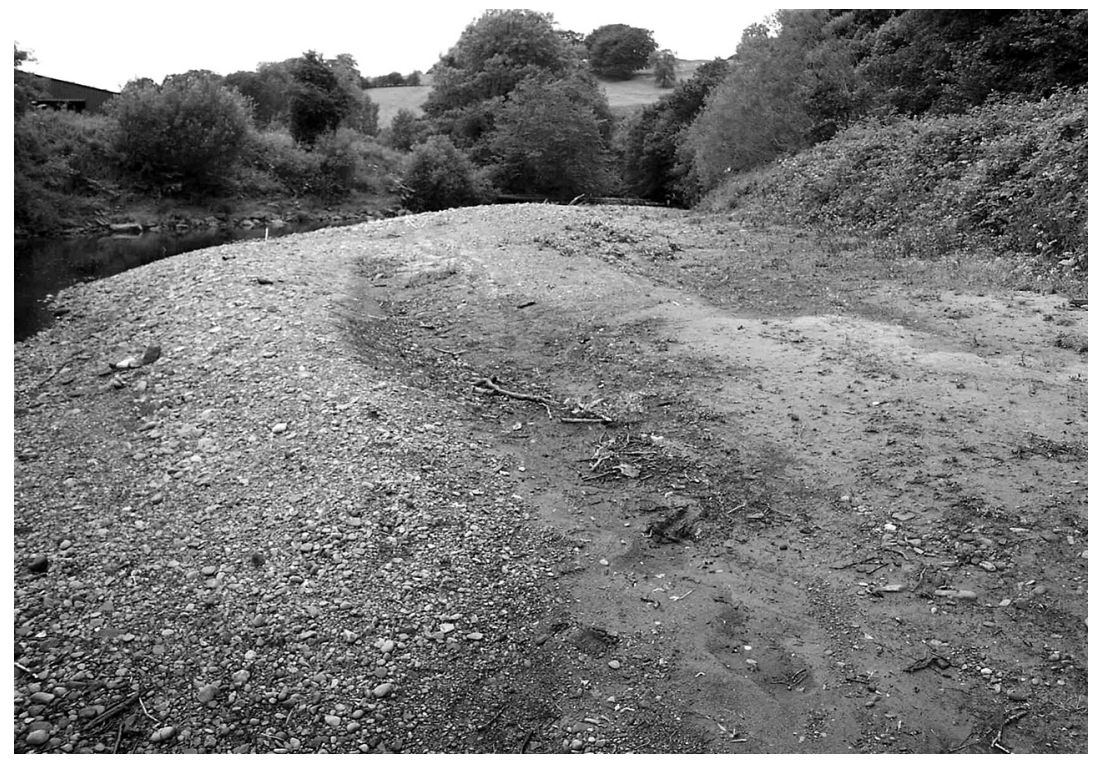

Fig. 4. Sand/shingle bar habitat of Tachydromia calcarata on the River Irthing, Cumbria, England. as the species was previously considered an exclusively Alpine Tachydromia, not found so far elsewhere in the Continent. Although the genus has been intensively studied for the last forty years in various biotopes of central Europe, and additional species described, T. calcarata has not been found since its original discovery in 1910 . The original type locality, the River Enns with its tributaries in the limestone Styrian Alps and with the marshy or gravel to stony riverbanks, clearly resembles the British biotopes of the King Water and River Irthing shown in Figs. 3 and 4. The average cold temperatures of the Styrian Alps compare well with the situation in Cumbria in the north of England, rather than with the warm lowlands of the continental central parts of Europe. Therefore, it is supposed that T. calcarata might well be more widely distributed in northern parts of continental Europe, also in the rather cold areas along the North Sea and Baltic coast, including southern Fennoscandia.

Acknowledgements. The authors thank the authorities of the Benedictine monastery in Admont for the privilege to study the Gabriel Strobl's Diptera Collection housed in the abbey. The study of further documentary material was financially supported by the grant No. 206/03/0284 of the Czech Grant Agency. The survey of river shingle insects in Cumbria was funded by English Nature and the Environment Agency.

\section{References}

Chvála, M. 1970: Revision of Palaearctic species of the genus Tachydromia Meig. (= Tachista Loew) (Diptera, Empididae). - Acta Ent. Mus. Nat. Pragae 38(1969): 415-524.

Chvála, M. 1973: Notes on British Tachydromia (Dipt., Empididae), with description of a new species from Inverness-shire. — Ent. Mon. Mag. 108 (1972): 214 218.

Chvála, M. 1975: The Tachydromiinae (Dipt. Empididae) of Fennoscandia and Denmark. - Fauna Ent. Scand., vol. 3, Scandinavian Science Press, Klampenborg, Denmark. 336 pp.

Chvála, M. 2003: Revision of the Hybotidae (Diptera) described by Gabriel Strobl from the Alps, with an annotated list of Strobl's localities and notes on the Admont Collection. - Acta Univ. Carol.-Biol. 47: 163-186.

Collin, J.E. 1961: Empididae. — In: British Flies, vol. 6, Cambridge University Press. 782 pp.

Hewitt, S. M. \& Chvála, M. 2002: Description of a new Western-European Tachydromia species (Diptera: Hybotidae) of the Tachydromia connexa-group. - $\mathrm{Br}$. J. Ent. Nat. Hist. 15: 65-70.

Hewitt, S. M., Atty, D. B., Parker, J., Read, R. J. W. \& Sinclair, M. 2005: Survey of the insects of exposed riverine sediments on the rivers Eden and Derwent in Cumbria in 2004. - Unpublished report to the English Nature and the Environment Agency.

Shamshev, I. V. 1993: New species of the genus Tachydromia Mg. (Diptera: Hybotidae) from Palaearctic Region: 1. terricola and interrupta-groups. Dipterological Research 4: 105-122.

Strobl, G. 1910: Die Dipteren von Steiermark. II. Nachtrag. — Mitt. Naturw. Ver. Steierm. 46 (1909): 45-292. 